\title{
USE OF INOCULUM IN BIODIGESTERS WITH CATTLE MANURE UNDER CONVENTIONAL AND ORGANIC PRODUCTION SYSTEMS
}

\author{
Juliana L. Paes ${ }^{1 *}$, Thaís B. S. Alves ${ }^{1}$, Leonardo D. B. da Silva ${ }^{1}$, Anieli de S. Marques ${ }^{1}$, \\ Valentina R. S. Dias ${ }^{2}$
}

${ }^{1 *}$ Corresponding author. Universidade Federal Rural do Rio de Janeiro/ Seropédica - RJ, Brasil.

E-mail: juliana.lobop@yahoo.com.br | ORCID ID: https://orcid.org/0000-0001-9301-0547

\section{KEYWORDS}

anaerobic

biodigestion, biogas, starting point, biofertilizer potential.

\begin{abstract}
One way of making livestock farming a more sustainable practice is to raise cattle organically. However, regardless of the production system, there is a generation of residues that can be converted into energy resources using biodigesters. This study aimed to evaluate the addition of inoculum in the anaerobic biodigestion of cattle manure under organic (OPS) and conventional production systems (CPS) in an Indian model biodigester. The physicochemical ( $\mathrm{pH}, \mathrm{EC}, \mathrm{TS}, \mathrm{VS}, \mathrm{DBO}$, and COD) and microbiological characteristics of the affluent and effluent, as well as the production, potential, and qualitative characteristics of the biogas, were evaluated. CPS showed higher reductions in TS, VS, BOD, and COD than OPS, with the highest effect of biogas production. Regarding the effect of inoculum addition, the treatment with $20 \%$ inoculum provided in both production systems high acceleration at the starting point of biogas production and increased energy potential, as well as high reductions in VS, BOD, and COD. Thus, there is a need to use $20 \%$ inoculum for high biogas productivity, regardless of the production system.
\end{abstract}

\section{INTRODUCTION}

Brazilian livestock farming stands out for its high economic and social importance, as it encompasses everything from food supply to job creation. Thus, there is an intense concern to apply the concept of sustainability in this activity. Lately, the cattle-raising system based on organic concepts has been disseminated among producers. Organic production can be described as an environmentally friendly, socially just, and economically viable production system for rural producers. In this type of production, animals are only provided with green manure from the pasture (Matias et al., 2015).

The livestock activity generates residues regardless of the form of raising. Therefore, attention must be paid to the correct disposition of the generated animal biomass because there is an intense discharge of nutrients, organic matter, and greenhouse gases that can harm the environment.

An alternative to reduce the negative impacts of these residues is the implementation of biodigesters in the agricultural environment. The anaerobic biodigestion process occurs inside the equipment, transforming biomass into alternative means of obtaining electric and thermal energy (biogas) and biofertilizer, which can be used in the production system of the rural property or commercialized (Castro et al., 2017; Kadam \& Panwar, 2017).

Biogas can also be commercialized in the carbon market, defined by the Kyoto protocol (Laramee \& Davis, 2013). According to Avaci et al. (2013), the sale of carbon credit provided a $60 \%$ reduction in energy production costs in the Brazilian pig industry.

Studies have indicated the benefits of using biofertilizers in the soil and agricultural production systems, which may be used as a substitute for conventional fertilizers (Laramee \& Davis, 2013; Koszel \& Lorencowics, 2015). From an economic point of view, chemical fertilizer costs can be reduced by approximately R\$ 146,000.00 per year (Avaci et al., 2013).

Although the use of biodigesters in the agricultural environment is quite beneficial, there is a long period of anaerobic biodigestion to begin biogas production (starting time) and reach its peak. According to Matos (2016), the starting time for anaerobic biodigestion of cattle manure under conventional and organic production systems in

${ }^{2}$ Universidade Federal Fluminense/ Niterói - RJ, Brasil. 
bench-top Indian model biodigesters occurred in five and four weeks, respectively. The main peak of production occurred after 13 and 9 weeks for the conventional and organic production systems, respectively.

Stirring and heating systems, co-digestion, and addition of inoculum can be used to circumvent this disadvantage (Silva et al., 2013; Chen et al., 2016; Cisneros-Pérez et al., 2017). However, stirring and heating mechanisms can be disadvantageous depending on the amount of energy used for their operation, making biodigesters costly.

A more economically viable alternative is the use of inoculum because, besides reducing the hydraulic retention time (HRT), the addition of this material maintains the biochemical processes lasting, reaching a high-quality biogas production $(\mathrm{Gu}$ et al., 2014; Maamri \& Amrani 2014). This procedure consists of using part of the material that has already undergone the anaerobic biodigestion process, providing the substrate to be digested with a stabilized population of microorganisms (Xavier \& Lucas Júnior, 2010). Different types of inocula have been used in the anaerobic biodigestion, such as swine manure, sewage sludge, cattle manure, and solid urban residues (ForsterCarneiro et al., 2007; Gu et al., 2014).

Thus, this study aimed to evaluate the effect of different inoculum proportions on the anaerobic biodigestion of cattle manure under conventional and organic production systems in Indian model biodigesters.

\section{MATERIAL AND METHODS}

The experiment was conducted at the Laboratory of Rural Electrification and Alternative Energy of the Engineering Department, belonging to the Institute of Technology of the Federal Rural University of Rio de Janeiro, campus of Seropédica, RJ, Brazil.

Bench-top Indian model biodigesters, consisting of a "water seal" containment chamber, fermentation chamber, gasometer, and U-bulb manometer with water as a manometric liquid, as described by Matos et al. (2017a), were used in the experiment.

Biodigesters were supplied with inoculum at proportions of 0,20 , and $40 \%$ together with raw material from dairy cattle manure under conventional (CPS) and organic production systems (OPS). The supply system was carried out in batches, i.e., the affluent was conditioned in the biodigester only at the beginning of the experiment, and the effluent was obtained after the 119-day HRT (17 weeks).

The manure used as raw material and inoculum came from cattle of the same origin and age. In both cases, manure was collected in a corral by scraping with a trowel. Cattle manure addition at different proportions in the biodigesters occurred within $24 \mathrm{~h}$ after collection to avoid loss of the biogas generated due to the early fermentation process.

Cattle manure under a conventional production system came from the Cattle Production Sector of PESAGRO-RJ. The cattle were fed on a Brachiaria pasture system together with commercial ration with $20 \%$ crude protein, cottonseed meal, corn, soybean, and supplementation with macronutrients and micronutrients (Matos et al., 2017a).
Cattle manure under the organic production system came from an integrated agroecological production system of Seropédica, RJ, Brazil. Girolando dairy cattle herd was fed on organically managed Brachiaria grass without mineral fertilization, receiving in the trough, when available, grass, sugarcane, and leguminous also from organic production during the drought period. Animals received no concentrate on their diet (Matos et al., 2017a).

Inoculum with cattle manure under CPS and OPS was produced in the biodigesters during a study carried out by Matos et al. (2017a) for 150 days. Biogas production at this HRT remained constant, indicating effluent stability in the biodigesters.

The preparation of the substrate used in the experiment was based on the standardization of the total solids content around 8\% (Salam et al., 2015). Water proportion added to the sample to obtain the working concentrations was determined from the results of the analysis of total solids.

The physicochemical characterization of the affluent and effluent of the biodigester was performed in terms of $\mathrm{pH}$, electrical conductivity (EC), total solids (TS), volatile solids (VS), biochemical oxygen demand (BOD), and chemical oxygen demand (COD). These analyses were carried out according to the methodology described by APHA (2005), as recommended by CONAMA Legislation 375/06 (Brasil, 2006). BOD and COD were determined according to the methodologies described by the methods 5210B and 5220D, respectively, of the Standard Methods for Examination of Water and Wastewater.

The produced biogas volume was calculated using the product of the vertical displacement of the gasometer by its inner cross-sectional area during HRT. Biogas volume correction for conditions of $1.0 \mathrm{~atm}$ and $20^{\circ} \mathrm{C}$ was carried out considering that the biogas presents a behavior close to the ideal, according to the compressibility factor, and using the expression resulting from the combination of the Boyle and Gay-Lussac laws.

Biogas production potentials were calculated using the weekly production data and amounts of the substrate, TS, and VS added to the biodigesters. The values were expressed as $\mathrm{m}^{3}$ of biogas per $\mathrm{kg}$ of the added substrate, TS, and VS.

Temperature monitoring of the environment and inside biodigesters was performed with a thermocouple connected to a millivoltmeter with an accuracy of $\pm 0.1^{\circ} \mathrm{C}$. The internal temperature was measured by inserting the thermocouple into the three-way valve fixed at the top of the campanula after biogas characterization. This point was adopted to measure the temperature because the highest microbial activity occurs in the upper region of the biodigester (Tavares et al., 2016). Gasometers were reset to zero after each reading using the three-way valve.

The evaluation of results of the anaerobic digestion test was carried out in a randomized block design, arranged in a $2 \times 3$ factorial, which consisted of the factors treatment (CPS and OPS) and inoculum proportions (IP), 0,20 , and $40 \%$. Eighteen biodigesters were used in the experiment, with each treatment and inoculum proportions in triplicates. 
The statistical analysis of the physicochemical characteristics ( $\mathrm{pH}, \mathrm{EC}, \mathrm{TS}$, and VS) of the affluent and effluent in CPS and OPS at different proportions were subjected to analysis of variance, followed by the Tukey test at the $5 \%$ probability level using the statistical software SISVAR v. 5.6. Graphs of weekly and accumulated production were constructed using the software Sigma Plot 2001 v. 7.0 for the Windows environment.

\section{RESULTS AND DISCUSSION}

\section{Qualitative evaluation of the affluent and effluent}

No statistical difference was observed between affluent and effluent, as well as between IP for treatments under conventional (CPS) and organic (OPS) production systems (Table 1).

TABLE 1. Average values of $\mathrm{pH}$ and electrical conductivity (EC) in the affluent (A) and effluent (E) of CPS and OPS treatments at different inoculum proportions (IP).

\begin{tabular}{|c|c|c|c|c|c|c|c|c|}
\hline \multirow{3}{*}{ IP (\%) } & \multicolumn{4}{|c|}{$\mathrm{pH}$} & \multicolumn{4}{|c|}{$\mathrm{EC}\left(\mathrm{dS} \mathrm{m}^{-1}\right)$} \\
\hline & \multicolumn{2}{|c|}{ A } & \multicolumn{2}{|c|}{$\mathrm{E}$} & \multicolumn{2}{|c|}{ A } & \multicolumn{2}{|c|}{$\mathrm{E}$} \\
\hline & CPS & OPS & CPS & OPS & CPS & OPS & CPS & OPS \\
\hline 0 & $6.6 \mathrm{ACa}$ & $8.2 \mathrm{BCa}$ & $6.5 \mathrm{ACa}$ & 7.6 $\mathrm{BCa}$ & $0.8 \mathrm{ACa}$ & $0.5 \mathrm{BCa}$ & $0.9 \mathrm{ACa}$ & $0.5 \mathrm{BCa}$ \\
\hline 20 & $6.8 \mathrm{ACa}$ & $8.0 \mathrm{BCa}$ & 6.6 ACa & 7.8BCa & $1.0 \mathrm{ACb}$ & $0.8 \mathrm{BCb}$ & $0.8 \mathrm{ADa}$ & $0.6 \mathrm{BDa}$ \\
\hline 40 & $6.9 \mathrm{ACa}$ & $8.2 \mathrm{BCa}$ & $6.8 \mathrm{ACa}$ & $8.0 \mathrm{BCa}$ & $0.9 \mathrm{ACab}$ & $0.7 \mathrm{BCb}$ & $0.8 \mathrm{ADa}$ & $0.6 \mathrm{BDa}$ \\
\hline
\end{tabular}

Means followed by different uppercase letters in the same row differ statistically from each other within animal production systems (A; B) and affluent and effluent (C; D) by the Tukey test at 5\% probability error.

Means followed by different lowercase letters in the same column differ from each other within proportions by the Tukey test at $5 \%$ probability error.

The $\mathrm{pH}$ in OPS showed a statistically high value in both affluent and effluent, regardless of the inoculum proportion, compared to CPS (Table 1). Matos et al. (2017b) evaluated the anaerobic biodigestion of dairy cattle manure and also found that CPS had $\mathrm{pH}$ values statistically higher than OPS.

Affluent and effluent in both production systems were established within the methanogenic range $(\mathrm{pH}$ between 6.0 and 8.2) for biogas production by microorganisms (Quadros et al., 2010; Sánchez-Hernández et al., 2013). However, the CPS treatment was more effective in maintaining the $\mathrm{pH}$ in the neutrality range at all IP (Table 1). In this production system, the $\mathrm{pH}$ values of the affluent and effluent were similar to those found by Xavier \& Lucas Júnior (2010) for dairy cattle manure substrates composed of 0,20 , and $40 \%$ inoculum.

The $\mathrm{pH}$ values resulting from anaerobic biodigestion of $8.7 \%$ sewage sludge, $7.9 \%$ bovine manure (Koszel \& Lorencowics, 2015), and 7.5\% co-digestion between manure of goats and sheep (Quadros et al., 2010), i.e., in the $\mathrm{pH}$ range of the OPS effluent, indicated the possibility of applying effluent as a biofertilizer.

The average values of electrical conductivity for CPS were significantly higher than for OPS in the affluent and effluent and between affluent and effluent for proportions of 20 and $40 \%$. The affluents from CPS and OPS presented a significant increase when using inoculum compared to the control (Table 1).
However, Matos et al. (2017b) observed results that differ from those found in this study, as EC of CPS was lower than that found for OPS for both the affluent and the effluent. However, as in the present study, the anaerobic biodigestion process resulted in a reduction of EC. According to Matos et al. (2017b), the reduction in EC indicates a possible reduction of dissolved salts during the anaerobic biodigestion process.

The application of saline irrigation water together with biofertilizer from cattle manure with EC of $0.8 \mathrm{dS} \mathrm{m}^{-1}$ (close to that obtained for the effluent of CPS) attenuated a reduction in leaf area, shoot dry matter, total dry matter, root length of peanut plants (Sousa et al., 2014). Besides these effects, irrigation with saline water and bovine manure biofertilizer attenuated the inhibition of the initial plant growth, reduced photosynthesis, transpiration, and stomatal conductance (Silva et al., 2011). In this sense, the beneficial effects of the application of biofertilizer from cattle manure on growth, gas exchange, and nutrient extraction were less expressive at the highest salinity levels of irrigation water (Silva et al., 2011).

The average values of TS and VS in the affluent and effluent showed no statistical difference $(\mathrm{P}>0.05)$ between CPS and OPS at all proportions (Table 2). The average TS values in the affluent of CPS and OPS were already expected, as the standardization was around $8 \%$. The VS content without inoculum showed a significant difference between the proportions of 20 and $40 \%$ (Table 2). 
TABLE 2. Average values of total solids (TS), volatile solids (VS) in the affluent (A) and effluent (E) of CPS and OPS treatments at different inoculum proportions (IP).

\begin{tabular}{|c|c|c|c|c|c|c|c|c|}
\hline \multirow{3}{*}{ IP (\%) } & \multicolumn{4}{|c|}{ ST (\%) } & \multicolumn{4}{|c|}{ SV (\%) } \\
\hline & \multicolumn{2}{|c|}{ A } & \multicolumn{2}{|c|}{ E } & \multicolumn{2}{|c|}{ A } & \multicolumn{2}{|c|}{ E } \\
\hline & CPS & OPS & CPS & OPS & CPS & OPS & CPS & OPS \\
\hline 0 & $8.1 \mathrm{ACa}$ & $8.3 \mathrm{ACa}$ & 6.6ADa & $6.8 \mathrm{ADa}$ & $73.7 \mathrm{ACa}$ & $73.0 \mathrm{ACa}$ & $62.4 \mathrm{ADb}$ & 64.4ADb \\
\hline 20 & $8.7 \mathrm{ACa}$ & 8.4ACa & 6.3ADa & 6.3ADa & 79.4ACb & $79.8 \mathrm{ACb}$ & $58.4 \mathrm{ADa}$ & 60.7ADa \\
\hline 40 & 8.3ACa & 8.6ACa & 6.2ADa & 6.9ADa & 78.4ACb & $78.2 \mathrm{ACb}$ & $59.5 \mathrm{Dab}$ & 61.7ADab \\
\hline
\end{tabular}

Means followed by different uppercase letters in the same row differ statistically from each other within animal production systems (A; B) and affluent and effluent (C; D) by the Tukey test at $5 \%$ probability error.

Means followed by different lowercase letters in the same column differ from each other within proportions by the Tukey test at $5 \%$ probability error.

Similar to TS values, VS values of the effluent in CPS and OPS were significantly lower than their respective affluent (Table 2). These results of TS and VS, when comparing the statistical difference between production systems, as well as the comparison between the affluent and effluent, were similar to those found by
Matos et al. (2017a).

Regarding the effect of production systems, affluent and effluent, and inoculum proportions, BOD and COD values (Table 3) showed a behavior similar to that found for TS and VS (Table 2).

TABLE 3. Values for a single sampling of biochemical oxygen demand (DBO) and chemical oxygen demand (COD) in the affluent (A) and effluent (E) of CPS and OPS treatments at different inoculum proportions (IP).

\begin{tabular}{|c|c|c|c|c|c|c|c|c|}
\hline \multirow{3}{*}{ IP (\%) } & \multicolumn{4}{|c|}{ DBO $\left(\times 10^{3} \mathrm{mg} \mathrm{L}^{-1}\right)$} & \multicolumn{4}{|c|}{$\mathrm{DQO}\left(\times 10^{3} \mathrm{mg} \mathrm{L}^{-1}\right)$} \\
\hline & \multicolumn{2}{|c|}{ A } & \multicolumn{2}{|c|}{$\mathrm{E}$} & \multicolumn{2}{|c|}{ A } & \multicolumn{2}{|c|}{$\mathrm{E}$} \\
\hline & CPS & OPS & CPS & OPS & CPS & OPS & CPS & OPS \\
\hline 0 & 17.82 & 13.30 & 15.69 & 12.09 & 57.75 & 43.18 & 46.28 & 36.85 \\
\hline 20 & 62.26 & 40.11 & 34.75 & 28.70 & 176.41 & 115.10 & 91.08 & 76.93 \\
\hline 40 & 32.36 & 22.52 & 25.37 & 19.54 & 97.42 & 70.30 & 67.50 & 51.00 \\
\hline CV (\%) & 1.65 & 1.86 & 2.65 & 2.42 & 1.83 & 2.10 & 3.05 & 2.70 \\
\hline
\end{tabular}

$\mathrm{CV}-$ coefficient of variation.

The CPS treatment showed a reduction in TS, VS, BOD, and COD higher than OPS (Table 4). The same behavior regarding TS and VS reductions was reported by Matos et al. (2017a).

TABLE 4. Reductions in total solids (TS), volatile solids (VS), biochemical oxygen demand (DBO), and chemical oxygen demand (COD) between affluent (A) and effluent (E) of CPS and OPS treatments at different inoculum proportions (IP).

\begin{tabular}{ccccccccc}
\hline \multirow{2}{*}{ IP (\%) } & \multicolumn{2}{c}{ TS (\%) } & \multicolumn{2}{c}{ VS (\%) } & \multicolumn{2}{c}{ DBO (\%) } & \multicolumn{2}{c}{ DQO (\%) } \\
\cline { 2 - 9 } & CPS & OPS & CPS & OPS & CPS & OPS & CPS & OPS \\
\hline 0 & 19 & 18 & 15 & 12 & 12 & 9 & 20 & 15 \\
20 & 27 & 22 & 26 & 24 & 44 & 28 & 48 & 33 \\
40 & 26 & 20 & 24 & 21 & 22 & 13 & 31 & 27 \\
\hline CV $(\%)$ & 5.51 & 10.00 & 3.70 & 3.04 & 1.57 & 1.66 & 2.29 & 2.65 \\
\hline
\end{tabular}

$\mathrm{CV}$ - coefficient of variation.

The highest reduction of TS, VS, BOD, and COD in CPS compared to OPS may be related to the roughagebased feeding of organic animals, as this food is more difficult to be digested by bacteria due to its high amount of fibrous compounds (Orrico Júnior, 2010; Xavier; 2010, Matos et al., 2017a).

Regarding the effect of proportions on TS, VS, BOD, and COD reductions, the factor inoculum influenced the results of the analyzed parameters (Table 4). The treatment without inoculum showed a lower reduction in TS, VS, BOD, and COD, indicating that the microbial population in the residue was not sufficient to decay organic matter efficiently at the 119-day HRT. However, a high capacity for adaptation is observed, leading to high reductions in TS, VS, BOD, and COD for the $20 \%$ inoculum proportion.
The efficiency in reducing organic matter when using inoculum in terms of TS, VS, and COD has been reported in several studies. Forster-Carneiro et al. (2007) reported reductions of 15 and $19 \%$ for VS and COD, respectively, for substrates with $25 \%$ inoculum of cattle manure in organic fractions of feed residues. Although the experiment carried out by these authors was carried out under thermophilic conditions $\left(55{ }^{\circ} \mathrm{C}\right)$, i.e., the temperature was higher than CPS and OPS, reductions in VS and COD were lower than the results obtained in production systems with $20 \%$ inoculum (Table 4 ).

According to Xavier \& Lucas Júnior (2010), reductions in VS varied from 22 to $42 \%$ during the dry period, with high values in substrates containing $40 \%$ inoculum of dairy cattle together with manure from the 
same origin. This variation range is within the VS reduction values for substrates under CPS and OPS containing 20 and $40 \%$ inoculum (Table 4). Orrico Júnior et al. (2010) reported reductions with variations of 46 and $61 \%$ for TS and 62 and $63 \%$ for VS for biodigesters with dairy cattle manure together with $15 \%$ inoculum and 120 days of HRT.

Studies aiming at the mathematical modeling of physicochemical parameters demonstrated that the influence of different types of inoculum followed a decreasing prediction model on the reductions in $\mathrm{pH}$, TS, VS, and COD (Rodrigues et al., 2014) and increasing on VS and COD (Leite et al., 2001; Lopes et al., 2004). Thus, mathematical modeling does not corroborate the presented results with high efficiency in reducing TS, VS, and COD obtained with a $20 \%$ inoculum proportion for CPS and OPS. The $40 \%$ inoculum proportion did not show an adaptation as efficient to the cattle manure under CPS and OPS conditions as that presented by $20 \%$ inoculum, probably due to factors already considered and related to the adaptation of microbial loads to the medium. Certain combinations of raw materials, together with inoculum and operational conditions, can result in a microbial imbalance

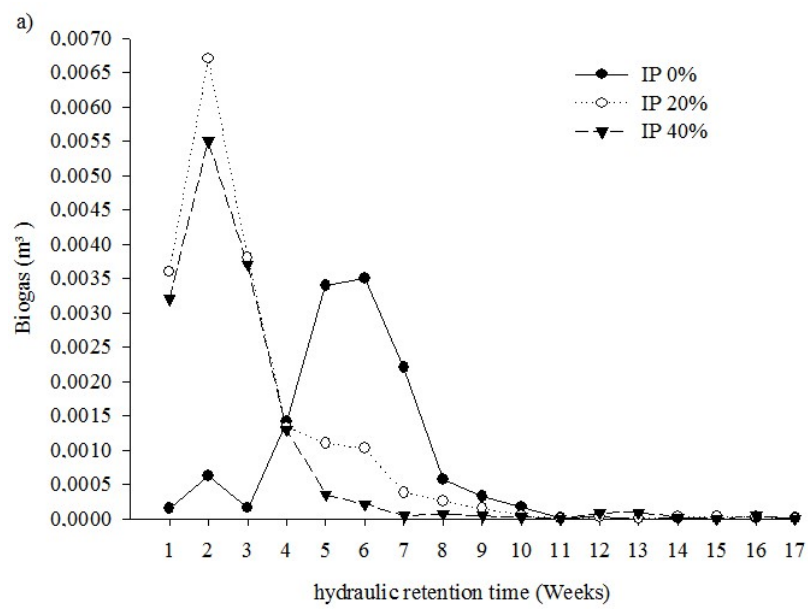

in the population or temporary reduction in its activity (Forster-Carneiro et al., 2007). Also, the reduction presented by $40 \%$ inoculum was higher than the reduction by $0 \%$ inoculum for all the analyzed parameters, characterizing the potential of using inoculum.

\section{Biogas production and energy potential}

Figure 1 shows that the starting point of biogas production occurred in the first week in biodigesters containing cattle manure and inoculum at proportions of 20 and $40 \%$ in both production systems. Moreover, an anticipation of the peak of biogas production was observed in the second week, while the biodigester without inoculum presented this peak only in the sixth week. In both cases, CPS had a higher value than OPS. The value reached at the peak of biogas production for 20 and $40 \%$ inoculum was, respectively, 48 and $60 \%$ for CPS and 54 and $52 \%$ for OPS, which were higher than the values observed for $0 \%$. As in the initial biogas production, the peak in biodigesters supplied with cattle substrates under CPS and OPS was higher at 20\% inoculum (Figure 1).

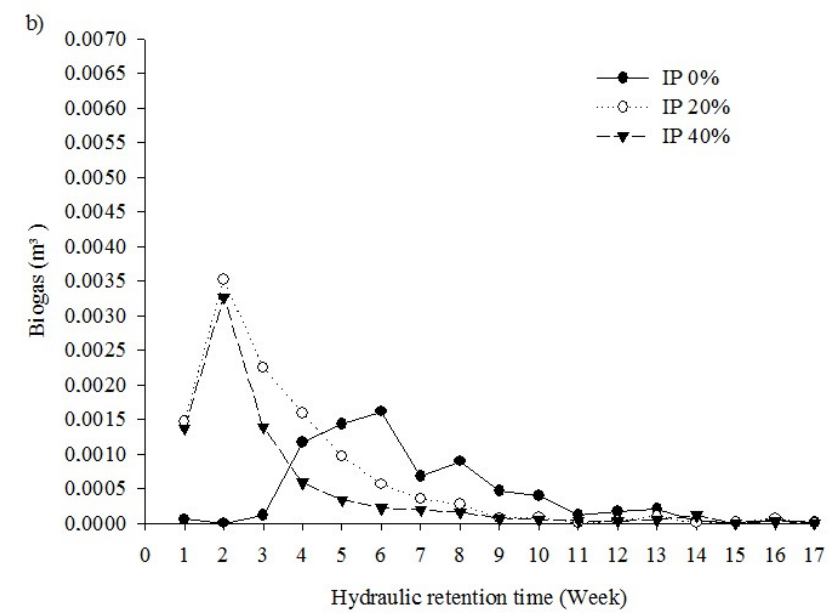

FIGURE 1. Weekly volumetric biogas production $\left(\mathrm{m}^{3}\right)$ at different inoculum proportions under the a) conventional production system (CPS) and b) organic production system (OPS).

The peak was followed by biogas production with small variations from the 11 th, 10 th, and 7 th week for 0,20 , and $40 \%$ inoculum, respectively, in CPS (Figure 1a). The peak in OPS was followed by a decrease up to the 14th and 11 th week and practically zero production for biodigesters without and with inoculum, respectively (Figure 1b). A more pronounced decrease in biogas production was observed for both systems with $40 \%$ inoculum.

The results observed by Matos (2016) corroborate those found in this study. The author verified a delay at the starting point and peak of biogas production in biodigesters supplied with conventional and organic cattle manure. The main peak of biogas production from cattle manure under the organic production system occurred in the 9th week, while under the conventional production system, it occurred only after 14 weeks of anaerobic digestion, but with higher production.

Xavier \& Lucas Júnior (2010) also verified the anticipation of the peak in treatments with inoculum, followed by a decrease until the production remained constant. According to these authors, the treatment with $40 \%$ inoculum showed a higher value and peak of biogas, differently from that obtained in this study. It may have occurred because the microbial load at a proportion of $20 \%$ inoculum adapts better to the medium compared to $40 \%$ inoculum. According to Forster-Carneiro et al. (2007), some combinations between manure, as well as operating conditions, can result in the microbiological imbalance or reduced activities.

The main purpose of using inoculum in cattle manure under conventional and organic production systems is due to the reduction of the starting time and optimization of the decay process.

The highest accumulated biogas production at the end of the anaerobic biodigestion process was observed for CPS (Table 5). Matos (2016) reported similar behavior, with an accumulated final biogas production after 210 days of anaerobic biodigestion lower than that achieved for the $0 \%$ inoculum proportion. According to the author, the conventional and organic production systems produced $11.15 \mathrm{~L}\left(0.0115 \mathrm{~m}^{3}\right)$ and $6.18 \mathrm{~L}\left(0.0068 \mathrm{~m}^{3}\right)$ of biogas, respectively. Moreover, the biodigesters used by Matos (2016) had the same dimensions and procedures adopted for biogas collection. 
TABLE 5. Accumulated production $\left(\mathrm{m}^{3}\right)$ and biogas production potentials per $\mathrm{kg}$ of substrate and total solids added $\left(\mathrm{TS}_{\text {add }}\right)$ and volatile solids added ( $\left.\mathrm{VS}_{\text {add }}\right)$ to different IP under CPS and OPS.

\begin{tabular}{ccccccccc}
\hline \multirow{2}{*}{ Proportion (\%) } & \multirow{2}{*}{ Accumulated production $\left(\mathrm{m}^{3}\right)$} & \multicolumn{4}{c}{ Potentials $\left(\mathrm{m}^{3}\right.$ of biogas $\left.\mathrm{kg}^{-1}\right)$} \\
\cline { 4 - 8 } & & & \multicolumn{2}{c}{ Substrate } & \multicolumn{3}{c}{$\mathrm{TS}_{\text {add }}$} & \multicolumn{4}{c}{$\mathrm{VS}_{\text {add }}$} \\
\cline { 3 - 9 } & CPS & OPS & CPS & OPS & CPS & OPS & CPS & OPS \\
\hline 0 & 0.0126 & 0.0074 & 0.0074 & 0.0044 & 0.0910 & 0.0527 & 0.1235 & 0.0721 \\
20 & 0.0185 & 0.0113 & 0.0109 & 0.0067 & 0.1254 & 0.0796 & 0.1579 & 0.0998 \\
40 & 0.0147 & 0.0079 & 0.0086 & 0.0046 & 0.1039 & 0.0542 & 0.1325 & 0.0692 \\
\hline$* \mathrm{CV}(\%)$ & & & 5.04 & 4.11 & 6.14 & 4.11 & 7.73 & 4.76 \\
\hline
\end{tabular}

$\mathrm{CV}-$ coefficient of variation.

As observed for reductions in TS, VS, BOD, and COD, the total produced biogas and the energy potential in CPS were higher than the values found in OPS for the $20 \%$ proportion, followed by 40 and $0 \%$ (Table 2). The highest values for the $20 \%$ proportion can be reflected in the ability to adapt to the microbiological load in the mixture between manure and inoculum. Also, the highest accumulated final biogas production for proportions of 20 and $40 \%$ relative to the treatment without inoculum characterized an improvement in the digestion of substrates when in association with cattle manure. On the contrary, Lopes et al. (2004) and Xavier \& Lucas Júnior (2010) reported that the accumulated biogas production was directly influenced by the percentage of inoculum since these parameters increased as the percentage of inoculum increased.

The results obtained by Vedrenne et al. (2008), Orrico Júnior et al. (2010), and Matos et al. (2017a) confirmed the efficiency of using inoculum aiming at increasing biogas production, with higher efficiency in CPS.

Matos et al. (2017a) carried out a 210-day anaerobic biodigestion experiment with room temperature ranging from 21 to $30{ }^{\circ} \mathrm{C}$ and the same bench-top Indian model biodigester prototype and observed that CPS showed higher energy potential than OPS. The authors obtained an accumulated biogas potential for CPS and OPS, respectively, of 0.21 and $0.12 \mathrm{~L}$ per $\mathrm{kg}$ of substrate, 2.53 and $1.40 \mathrm{~L}$ per kg of added total solids, and 12.71 and $7.04 \mathrm{~L}$ per kg of added volatile solids, which were lower than the results found for $0 \%$ proportion in CPS and OPS (Table 5).

Vedrenne et al. (2008) compared anaerobic biodigestion between cattle manure under conventional and organic production systems, each with $50 \%$ swine inoculum, and found that the highest accumulated biogas production was observed in CPS compared to OPS. Also, accumulated biogas productions of approximately 0.3000 $\mathrm{m}^{3} \mathrm{~kg} \mathrm{VSadd}{ }^{-1}$ for CPS and $0.2400 \mathrm{~m}^{3} \mathrm{~kg} \mathrm{VSadd}^{-1}$ for OPS were lower than the results found in this study, probably due to swine-origin inoculum, in addition to higher HRT (153 days) and temperature $\left(30{ }^{\circ} \mathrm{C}\right)$. Regarding the effect of using the swine-origin inoculum, dairy cattle manure has lower yields than pig manure when submitted to anaerobic digestion, mainly due to fibrous constituents that limit the residue digestion capacity (Orrico et al., 2016).

Orrico Júnior et al. (2010) evaluated the effect of the diet and observed that biogas production potential for animals fed higher $\left(0.37 \mathrm{~m}^{3} \mathrm{~kg} \mathrm{TS}^{-1}\right)$ and lower $\left(0.42 \mathrm{~m}^{3}\right.$ $\mathrm{kg} \mathrm{TS}^{-1}$ ) roughage proportion was lower to that found in the present study for both CPS and OPS with inoculum. In this case, the low decay of dairy cattle substrates from the diet with high roughage proportion (slow and difficult degradation materials) interferes with biogas production potentials, corroborating the results found here.

The effect of fibrous substances on the anaerobic biodigestion process can be confirmed in a study carried out by Galbiatti et al. (2010). These authors found that codigestion between $50 \%$ of cattle manure and $50 \%$ of sugarcane bagasse resulted in a $31 \%$ reduction in the accumulated biogas production after 120 days of anaerobic biodigestion.

Regarding the effect of proportions, CPS and OPS with $20 \%$ inoculum provided higher energy potential, followed by proportions of 40 and $0 \%$ (Table 5).

\section{Effect of temperature on biogas production}

Figure 2 shows that the internal temperatures of the biodigester followed the environmental behavior. Giacobbo et al. (2013) and Tavares et al. (2016) observed this same behavior when evaluating biogas production in a Bioköhler biodigester. 


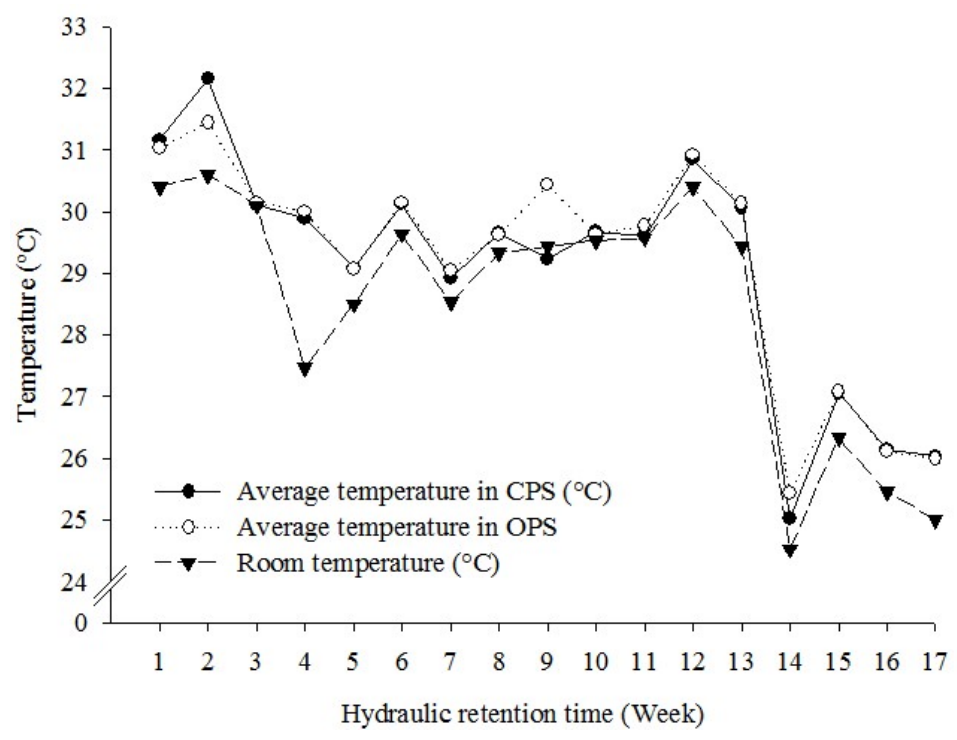

FIGURE 2. Average weekly variation of the internal temperature of the biodigester and room temperature.

Moreover, room temperature remained below the internal temperature of biodigesters throughout the anaerobic biodigestion process. In this case, the insulation with a water seal was efficient for maintaining higher temperatures inside the biodigesters.

Regarding the effect of temperature on the anaerobic biodigestion process, the sharp decline in the temperature inside the biodigesters between the 12th and 14th week (Figure 2) showed no interference with biogas production. During this period, biogas production in biodigesters with $40 \%$ inoculum under CPS and 0 and $20 \%$ under OPS showed a slight increase, followed by a generation tending to zero (Figure 1). Although no variation was observed inside the biodigester (Figure 2), the average temperatures remained within an acceptable range (mesophilic) for biogas production (Salam et al., 2011; 2015). According to Tavares et al. (2016), drastic reductions in biogas production occur when there is a drop in the internal temperature, influenced by a decrease in the ambient temperature, below $20{ }^{\circ} \mathrm{C}$. Probably, biogas production was not affected due to the ability of mesophilic bacteria to adapt to temperature variations that occur smoothly (Chae et al., 2008). Also, biogas production is not immediately affected by a decrease in temperature to the lower limit of the mesophilic phase (Tavares et al., 2016). Although variations occurred during the anaerobic biodigestion process, the temperatures inside biodigesters remained within the mesophilic range.

\section{CONCLUSIONS}

CPS presented higher reductions in TS, VS, BOD, and COD than OPS because food components were more easily degraded. The treatment with $20 \%$ inoculum addition in the biodigester provided higher acceleration for the starting point and increased energy potential, expressed as biogas production per $\mathrm{kg}$ of substrate, due to high adaptability of the microbial load, followed by proportions of 40 and $0 \%$.

\section{REFERENCES}

APHA - American Public Health Association (2005)

Standard methods for examination of water and wastewater. Washington, American Water Works Association, $21^{\text {th }}$ ed. p1386.

Avaci AB, Souza SNM, Chaves LI, Nogueira CEC, Niedzialkoski RK, Secco D (2013) Avaliação econômicofinanceira da microgeração de energia elétrica proveniente de biogás da suinocultura. Revista Brasileira de Engenharia Agrícola e Ambiental 17:456-462.

Brasil (2006) Ministério do Meio Ambiente. Conselho Nacional do Meio Ambiente. Resolução CONAMA n ${ }^{\circ}$ 375, de 29 de agosto de 2006. Define critérios e procedimentos para o uso agrícola de lodos de esgoto gerados em estações de tratamento de esgoto sanitário e seus produtos derivados. Diário Oficial da República Federativa do Brasil, Brasília, DF, n 167, p141-146.

Castro L, Escalante H, Jaimes-Estévez J, Díaz, LJ, Vecino K, Rojas G, Mantilla L (2017) Low cost digester monitoring under realistic conditions: Rural use of biogás and digestate quality. Bioresource Technology 239:311-317.

Chae KJ, Jang A, Yim SK, Kim IS (2008) The effects of digestion temperature and temperature shock on the biogas yields from the mesophilic anaerobic digestion of swine manure. Bioresource Technology 99:1-6.

Chen R, Ross MM, Zhong Y, Marsh T, Roman MB, Ascencio WH, Uribe L, Lorio LU, Kirk D, Reinhold DM, Chavarria JAM, Ruiz DB, Pereira JFA, Montero WR, Srivastava A, Liao W (2016) Responses of anaerobic microorganisms to different culture conditions and corresponding effects on biogas production and solid digestate quality. Biomass and Bioenergy 85:84-93.

Cisneros-Pérez C, Etchebehere C, Celis L, Carrillo-Reyes J, Alatriste-Mondragón F, Razo-Flores E (2017) Effect of inoculum pretreatment on the microbial community structure and its performance during dark fermentation using anaerobic fluidized-bed reactors. International Journal of Hydrogen Energy 42:9589-9599. 
Forster-Carneiro T, Pérez M, Romero LI, Sales D (2007) Dry-thermophilic anaerobic digestion of organic fraction of the municipal solid waste: focusing on the inoculum sources. Bioresource Technology 98:3195-3203.

Galbiatti J, Caramelo A, Silva F, Gerardi E, Chiconato D (2010) Estudo qualiquantitativo do biogás produzido por substratos em biodigestores tipo batelada. Revista Brasileira de Engenharia Agrícola e Ambiental 14:432-437.

Giacobbo G, Zenatti DC, Feiden A, Blanco MFJ, Tietz CM, Weber R (2013) Influência da variabilidade da temperatura ambiente na co-digestão anaeróbia de dejetos de bovinocultura de leite e cama de aviário. Acta iguazu 2:55-69.

Gu Y, Chen X, Liu Z, Zhou X, Zhang Y (2014) Effect of inoculum sources on the anaerobic digestion of ricestraw. Bioresource Technology 158:49-155.

Kadam R, Panwar NL (2017) Recent advancement in biogas enrichment and its applications. Bioresource Technology 73:892-903.

Koszel M, Lorencowics E (2015) Agricultural use of biogas digestate as a replacement fertilizers. Agriculture and Agricultural Science Procedia 7:119-124.

Laramee J, Davis J (2013) Economic and environmental impacts of domestic bio-digesters: Evidence from Arusha, Tanzania. Energy for Sustainable Development 17:296-304.

Leite VD, Lopes WS, Prasad S (2001) Bioestabilização anaeróbia de resíduos. Revista Brasileira de Engenharia Agrícola e Ambiental 5:119-123.

Lopes WS, Leite VD, Prasad S (2004) Influence of inoculum on performance of anaerobic reactors for treating municipal solidwaste. Bioresource Technology 94:261-266.

Maamri S, Amrani M (2014) Biogas production from waste activated sludge using cattle dung inoculums: effect of total solid contents and kinetics study. Energy Procedia 50:352-359.

Matias MJA, Azevedo DB, Calia RC, Malafaia GC (2015) Práticas sustentáveis na bovinocultura de corte orgânica em Mato Grosso do Sul: o caso da ABPO. Organizações Rurais \& Agroindustriais 17:209-224.

Matos CF (2016) Produção de biogás e biofertilizante, a partir de dejetos de bovinos, sob sistema orgânico e convencional de produção. Seropédica. Dissertação Mestrado, Seropédica, Instituto de Tecnologia, Departamento de Engenharia, Universidade Federal Rural do Rio de Janeiro.

Matos CF, Paes JL, Pinheiro EFM, Campos DVB (2017a) Biogas production from dairy cattle manure, under organic and conventional production systems. Engenharia Agrícola 37:1081-1090.

Matos CF, Pinheiro EFM, Paes JL, Lima E, Campos DVB (2017b) Avaliação do potencial de uso de biofertilizante de esterco bovino resultante do sistema de manejo orgânico e convencional da produção de leite. Revista Virtual de Química 9:1957-1969.
Orrico ACA, Lopes WRT, Manarelli DM, Orrico Júnior MAP, Sunada NS (2016) Codigestão anaeróbia dos dejetos de bovinos leiteiros e óleo de descarte. Revista Engenharia Agrícola 36:537-545.

Orrico Júnior MAP, Orrico ACA, Lucas Júnior J (2010) Influência da relação volumoso: concentração e do tempo de retenção hidráulica sob a biodigestão anaeróbia de dejetos de bovinos, Revista Engenharia Agrícola 30:386-394.

Quadros DG, Oliver APM, Regis U, Valladares R, Souza PHF, Ferreira EJ (2010) Biodigestão anaeróbia de dejetos de caprinos e ovinos em reator contínuo de PVC flexível. Revista Brasileira de Engenharia Agrícola e Ambiental 14:326-332.

Rodrigues JP, Orrico ACA, Orrico Júnior MAP, Seno LO, Araújo LC, Sunada NS (2014) Adição de óleo e lipase sobre a biodigestão anaeróbia de dejetos suínos. Revista Ciência Rural 44:544-547.

Salam B, Biswas S, Das TK (2011) Biogas from thermophilic anaerobic digestion of cow dung. In: International Conference on Mechanical Engineering, Kuantan, IOP Publishing.

Salam, B, Biswas S, Rabbi MS (2015) Biogas from Mesophilic Anaerobic Digestion of Cow Dung Using Silica Gel as Catalyst. Procedia Engineering 105:652-657.

Sánchez-Hernández EP, Weilanda P, Borjab R (2013) The effect of biogas sparging on cow manure characteristics and its subsequent anaerobic biodegradation. International Biodeterioration \& Biodegradation 83:10-16.

Silva FLB, Lacerda CF, Sousa GG, Neves ALR, Silva, GL, Sousa, CHC (2011) Interação entre salinidade e biofertilizante bovino na cultura do feijão-de-corda. Revista Brasileira de Engenharia Agrícola e Ambiental 15:383-389.

Silva WTL, Novaes AP, Kuroki V, Martelli LFA, Magnoni Júnior L (2013) Avaliação físico-química de efluente gerado em biodigestor anaeróbio para fins de avaliação de eficiência e aplicação como fertilizante agrícola. Quimica Nova 35:35-40.

Sousa GG, Lima FA, Gomes KR, Viana TVA, Costa FRB, Azevedo BM, Martins LF (2014) Irrigação com água salina na cultura do amendoim em solo com biofertilizante bovino. Nativa 2:89-94.

Tavares SG, Feiden A, Correia AF, Soarez CMT, Gregolin MRP (2016) Influência das variações térmicas e climáticas na produção de biogás. Nativa 4:287-295.

Vedrenne F, Béline F, Dabert P, Bernet N (2008) The effect of incubation conditions on the laboratory measurement of the methane producing capacity of livestock wastes. Bioresource Technology 99:146-155.

Xavier CAN, Lucas Júnior J (2010) Parâmetros de dimensionamento para biodigestor batelada operados com dejetos de vacas leiteiras com e sem uso de inóculo. Revista Engenharia Agrícola 30:212-223. 